\title{
Entrevista com Eduardo Viveiros de Castro
}

\section{Por Cleber Lambert \& Larissa Barcellos*}

Eduardo Viveiros de Castro é antropólogo e professor titular do programa de pós-graduação em antropologia social no Museu Nacional da Universidade Federal do Rio de Janeiro. Esta entrevista foi realizada durante o $3^{\circ}$ Forum International de Philosophie Politique et Sociale, que ocorreu entre os dias 8 e 16 de julho de 2011 na Université de Toulouse 2 Le Mirail, em Toulouse (França). Coordenado por Jean-Christophe Goddard, esse simpósio foi organizado em torno de dois temas principais, a saber, "descolonização" e "transversalidade", encerrando o ano escolar 2010/2011 da Equipe de Pesquisa Sobre as Racionalidades Filosóficas e os Saberes (ERRAPHIS), do Departamento de Filosofia, ano caracterizado pelo esforço em se praticar a transversalidade com outros saberes: geografia, artes, biologia, urbanismo, política e antropologia. Durante o simpósio, Eduardo Viveiros de Castro apresentou alguns dos temas abordados em seu livro Métaphysiques Cannibales (2009).

Primeiros Estudos: $O$ que o senhor chama de experiência de pensamento, e como isso se relaciona com o trabalho de campo na antropologia?

Eduardo Viveiros de CaSTro: A noção de experiência de pensamento é uma ideia clássica em filosofia. Os filósofos gostam muito de fazer experiências de pensamento, "experiências" no sentido de experimentos. "Experiências de pensamento" significa experimentações imaginárias, feitas em pensamento. Eu usei essa expressão alguma vez, acho que em meu artigo "O nativo relativo" (2002), mas deturpando um pouco o sentido canônico da expressão, até porque eu estava usando isso para falar de antropologia. Usei a palavra experiência em seu duplo sentido, tanto no de ${ }^{*}$ Doutorando em Filosofia - UFSCar e graduanda em Ciências Sociais - USP. Todas as notas de rodapé inseridas
ao longo desta entrevista são dos entrevistadores. 
ter uma experiência como no de fazer uma experiência. Sobretudo, no de fazer uma experiência com o pensamento alheio, e não no próprio pensamento.

Aquilo que os filósofos chamam experimento/experiência de pensamento é um experimento mental, seja porque fazer esse experimento materialmente é muito difícil ou impossível, seja porque o que se quer provar é um ponto teórico: imagine um marciano que chega na Terra e tenta comprar um cigarro. Imagine um selvagem - quem gosta muito disso são os filósofos analíticos, de tradição anglosaxã -, [imagine] o quarto chinês de Searle ${ }^{1}$ ou o gavagai de Quine ${ }^{2}$ : como é que você descobre que a palavra gavagai que você ouve dita por um selvagem, em uma língua que você desconhece, quando passa um coelho na frente de você e dele, como saber que ela denota o animal coelho e não pata do coelho, ou a orelha do coelho, ou a corrida do coelho?

Bem, no meu caso, fiz uma experiência de pensamento com a noção de experiência de pensamento. Propus definir a antropologia como uma metafísica experimental, que realiza experimentos com o pensamento alheio, o pensamento indígena, tomando-o, por exemplo, como um pensamento filosófico. Como se aquilo que os índios estivessem pensando exprimisse "um pensamento", como se fala em "pensamento grego", "pensamento pré-socrático" etc. Vamos tomá-lo como se fosse, o que não quer dizer que ele não seja. Vamos tomá-lo nesse sentido específico, como representando um pensamento. Experimentar esse pensamento, pensar como, imaginar como seria pensar como um índio. E ao mesmo tempo é pensar com o pensamento indígena, porque pensar como o pensamento indígena a gente sabe que só poderia fazer em pensamento, não se pode fazer na realidade porque nós não somos indígenas, mas pensar com esse pensamento é algo que não só se pode como eu entendo que se deve, é um experimento de pensamento fundamental.

A antropologia sempre foi concebida e praticada como um discurso sobre os outros, os índios, por exemplo. Estava na hora - não fui o primeiro de jeito nenhum a dizer isso - de dizer com todas as letras que a antropologia precisa pensar com o

\footnotetext{
${ }^{1}$ John Searle é filósofo e professor na Universidade de Berkeley, Califórnia (EUA).

2 Importante filósofo analítico do século XX.
} 
pensamento indígena, e não pensar simplesmente sobre o pensamento indígena. Tomar esse pensamento como interlocutor, eventualmente polêmico, talvez antagonista, como interlocutor à sua altura, à altura do pensamento antropológico, e não como algo que está em posição de objeto, e você ali em atitude de sobrevoo, em posição de dominância sobre esse pensamento. 0 antropólogo como aquele que conhece as razões que esse pensamento não conhece. As razões desse pensamento que esse pensamento não conhece.

A relação disso com o campo é que essa experiência de pensamento tem que ser feita com base em uma experiência de campo, seja a sua própria, seja a alheia não precisa ser a sua própria. A relação do antropólogo com a própria experiência é claro que é especial, mas ela não é tão especial assim a ponto de distingui-la absolutamente da experiência que outros antropólogos tiveram com outros povos em outras situações. Todo antropólogo lança mão da experiência alheia, do campo alheio, criticando-a evidentemente, mas como você critica a sua própria, duvida da sua própria, problematiza a sua própria. Na verdade, é sempre pela experiência de campo que a coisa passa, porque a antropologia é sim etnografia, trabalho de campo, o seu próprio ou o alheio.

Quando eu digo que a antropologia é trabalho de campo, não quero dizer, portanto, que o antropólogo só pode pensar baseado em seu próprio campo. Isso seria um absurdo. Senão você não poderia fazer mais nada, ninguém pensaria nada a não ser o seu próprio campo, e não haveria diálogo possível, você não teria o que dizer para ninguém porque ninguém teve a sua experiência de campo. Agora, a todo antropólogo, no meu entender, não faz mal nenhum ter uma experiência de campo, muito pelo contrário. É importantíssimo, mesmo que ele nem venha a pensar principalmente sobre a sua própria [experiência]. Há antropólogos cuja experiência de campo não constituiu necessariamente a principal experiência com o campo. Lévi-Strauss talvez seja um caso exemplar nesse sentido. Sua experiência de campo foi importantíssima para dar o tom de sua antropologia, para dar a qualidade afetiva - um afeto no sentido espinozista do termo - de sua visão sobre os índios; mas certamente ela não constituiu o principal de seus experimentos. Sua pesquisa de campo foi feita nas bibliotecas. Lévi-Strauss tinha uma erudição monstruosa e uma intuição prodigiosa. Ele leu tudo o que foi escrito sobre a etnografia 
ameríndia da sua época; sua experiência de campo se soma, na verdade, à experiência de campo de centenas de pesquisadores.

Primeiros Estudos: $O$ senhor poderia falar um pouco sobre a descolonização permanente do pensamento e por que acentuar o permanente dessa expressão?

Eduardo Viveiros de CASTRo: Essa expressão “descolonização do pensamento” não chega a ser uma invenção minha. Eu a devo ter lido em algum lugar, embora não lembre se li, nem onde. Ela surgiu para mim em um contexto dialógico, no debate que travei com meu amigo Philippe Descola ${ }^{3}$ em janeiro de 2009, mediado por Bruno Latour4. Não lembro por que exatamente, a horas tantas retorqui: "não, temos que fazer a descolonização: a antropologia é a descolonização permanente do pensamento"5. A palavra "permanente" remete é claro ao topos trotskista da revolução permanente. A alusão à revolução permanente era provocativa; o que eu queria dizer era: "nós não estamos aqui para fazer taxonomia, nem para organizar cognitivamente o mundo; nós estamos aqui para fazer uma revolução permanente”. Uma revolução "em pensamento", "no pensamento". Uma descolonização permanente do pensamento.

A antropologia precisa saber aproveitar a oportunidade que foi dada a ela por ter sobrevivido à descolonização, ela que se constituiu num contexto institucional, teórico e epistemológico colonial, mas que conseguiu sobreviver a esse contexto. Aos trancos e barrancos, mas sobreviveu. Em alguns lugares, sobreviveu mal. Parece-me, por exemplo, que ela sobreviveu muito mal nos Estados Unidos, cuja academia está, em muitos casos, vivendo muito mal essa experiência, tendo entrado em uma espiral vertiginosa de autocrítica e de autoculpabilidade que administra pessimamente. Outras antropologias estão se saindo relativamente bem. Acho que a inglesa está se saindo bem nesse processo. A francesa eu não sei dizer se está

\footnotetext{
3 Philippe Descola é antropólogo americanista e professor no Collège de France, em Paris (França). (N. dos Entrevistadores.)

${ }^{4}$ Bruno Latour é professor de sociologia na Sciences Po Paris (França). Seus trabalhos na área dos sciences studies têm exercido grande influência tanto na sociologia quanto na antropologia da ciência. (N. dos Entrevistadores.)

50 vídeo do debate está disponível no endereço: <www.archivesaudiovisuelles.fr/FR/_video.asp?id=1664\& $\underline{\text { ress }}=6193 \&$ video $=131090 \&$ format $=69>$.
} 
se saindo bem ou mal nesse processo, até porque, talvez, nesse país, não seja a antropologia que esteja na vanguarda da questão da descolonização do pensamento, mas a filosofia, como estamos a testemunhar neste simpósio aqui em Toulouse. A descolonização antropológica do pensamento começou aqui pela filosofia, penso eu, ou melhor, pela incorporação filosófica da problemática da antropologia estrutural. Pelo "momento estruturalista" do pensamento francês nos anos de 1960, sobre o qual Patrice Maniglier ${ }^{6}$ tem escrito textos fundamentais, no que concerne à influência da antropologia de Lévi-Strauss sobre o campo filosófico francês. Foi assim que eu experimentei a antropologia na época que me formei na disciplina como algo que se conectava com a filosofia, com a linguística, com a psicanálise.

Lévi-Strauss propôs com Raça e História - um livro de 1952, que as pessoas tratam assim meio en passant, mas que é importantíssimo -, uma crítica dos fundamentos metafísicos do colonialismo. Ele mostrou que não havia nenhuma razão para que a cultura ocidental se considerasse superior. Não foi o primeiro a fazê-lo, mas ele o faz, nesse livro, de maneira especialmente sintética, eloquente. Raça $e$ Historia é uma das pré-condições, no meu entender, para o que vai se seguir anos mais tarde: a crítica dos fundamentos colonialistas da metafísica empreendidas pelos filósofos dos anos de 1960, Derrida, Foucault, Deleuze.

A descolonização do pensamento antropológico significa uma dupla descolonização: assumir o estatuto integral do pensamento alheio enquanto pensamento e descolonizar o próprio pensamento. Deixar de ser o colonialista de si mesmo, subordinado às ideias mestras, às ideias-chave de sujeito, autoridade, origem, verdade. A descolonização envolve esse duplo movimento, o reconhecimento da descolonização histórica, sociopolítica do mundo, e os efeitos que isso tem sobre a descolonização do pensamento. Nenhum dos dois processos jamais estará completo e terminado, nem a descolonização do mundo, nem a do pensamento. 0 adjetivo "permanente" significa, por isso, que o pensamento tem uma tendência natural ao colonialismo; a inércia do pensamento conduz o pensamento a se acomodar em soluções milagrosas, em esquemas fáceis, mecânicos, rígidos, um certo colonialismo intrínseco de todo pensamento. Evita-se, assim, transformar o pensamento em

\footnotetext{
6 Patrice Maniglier é professor de filosofia na University of Essex (Reino Unido).
} 
doutrina, em igreja, seita. Resisti-se à padronização, à normatização, à paradigmatização do pensamento mesmo.

Primeiros Estudos: O senhor falou dos anos de 1960 e citou alguns filósofos, mas lembra também o Debord7 , não é?

Eduardo Viveiros de Castro: Guy Debord, que eu confesso com imensa vergonha que eu conheço mal... Li pouco. Você fala do Sociedade do espetáculo (1997)?

Primeiros Estudos: Do Sociedade do espetáculo e também do situacionismo, e das situações construídas, e justamente nesse contexto de descolonização, do póscolonialismo ${ }^{8}$.

Eduardo Viveiros de CASTRo: Tenho preconceito favorável ao trabalho de Debord, mas o conheço mal. Gosto muito dessas coisas que aconteceram aqui na França e que aparentemente não foram levadas realmente a sério dentro da academia. Como a revista Tiqqun ${ }^{9}$ e o livro $A$ insurreição que virá ${ }^{10}$ (à venir), que me parecem extremamente interessantes. Não vi grande impacto no plano da academia dessas iniciativas. Pode ser ignorância minha. A Tiqqun é uma revista importantíssima, no meu entender, e que representa uma das pontas mais interessantes do que eu chamo de anarquismo ontológico. Assim como esse livro, A insurreição que virá, parcialmente inspirado por Agamben ${ }^{11}$, mas que, no meu entender, é um pouco mais selvagem que o Agamben. O livro não foi levado muito a sério, foi considerado uma estudantada, mas é um livro que deveria ter uma função importante no pensamento de esquerda atual.

\footnotetext{
7 Guy Debord foi um ativista francês, fundador do movimento Internacional Situacionista, que exerceu grande impacto nos acontecimentos de 1968 na França.

8 Situacionismo: movimento radical de esquerda, liderado por Debord do final dos anos de 1950 até sua extinção, no início da década de 1970. Propôs, por meio da fusão da arte e política, a superação das dicotomias do capitalismo tardio, por ele denominado "sociedade do espetáculo".

9 Tiqqun: revista de vanguarda francesa. 0 endereço eletrônico da revista é: <http://bloom0101.org/tiqqun. html>.

100 livro encontra-se disponível em francês no endereço: www.bloom0101.org/pdf_Insurrection.pdf.

11 Provável referência ao trabalho A comunidade que vem (1993) do filósofo italiano Giorgio Agamben, ele próprio influenciado por Guy Debord.
} 
Primeiros Estudos: O seu livro mais recente, Métaphysiques Cannibales (2009), ultrapassa os limites acadêmicos entre a filosofia e a antropologia, e o senhor mesmo falou hoje que ele não é um livro de filosofia, mas um livro contra a antropologia e para filósofos. Como o senhor faz a conexão entre a antropologia e a filosofia?

Eduardo Viveiros de CASTro: Esse livro não tem quase nada de novo em relação ao que eu já publiquei em diferentes lugares. Ele nada tem de original, nada de inédito. Foi escrito para o público francês, francófono; quase todos os pedaços do livro tinham saído já em português ou em inglês. Ele reescreve quatro conferências que dei aqui na França em janeiro de 200912. Ao reescrevê-lo, fundi diferentes trabalhos, desde um artigo sobre Deleuze que escrevi em inglês e que saiu também em português na Novos Estudos ${ }^{13}$, o artigo “O nativo relativo" (2002), outras coisas... Enfim, são vários textos esparsos que consolidei, fundi, soldei num livro só. Acho que a solda se vê, não é um livro muito bem integrado assim em capítulos. Mas a ideia era trazer para um público francês, e sobretudo para um público mais de filósofos do que de antropólogos, porque os antropólogos locais, em princípio, supostamente conheciam esses artigos no original, sobretudo meus colegas americanistas. A minha ideia era trazer a discussão para fora da antropologia, até porque eu havia trazido para dentro da antropologia boa parte dos temas e das questões que eu, então, devolvia agora para a comunidade filosófica. Esses artigos têm uma ambição - no sentido positivo e negativo do termo - filosófica.

Esse meu livro é um dos dois que inaugura uma coleção de filosofia intitulada MétaphysiqueS, dirigida por Patrice Maniglier (que foi quem me convidou), por Quentin Meillassoux ${ }^{14}$, filho de Claude Meillassoux ${ }^{15}$, e por David Rabouin ${ }^{16}$ (posso

\footnotetext{
12 Os vídeos das apresentações estão disponíveis em: <www.archivesaudiovisuelles.fr/1664/videos.asp?id= $1664>$.

13 Trata-se do artigo "Filiação intensiva e aliança demoníaca” (VIVEIROS DE CASTRO, 2007).

14 Quentin Meillassoux é um dos filósofos dessa nova geração cujos nomes são arrolados por Viveiros de Castro e que se encontram em torno da Coleção MetaphysiqueS. Professor na Ecole Normale Supérieur Ulm, Meillassoux integra o movimento "realismo especulativo", que reúne outros nomes. Crítico da herança epistemológica que dominou a filosofia após Kant, Meillassoux reata com a tradição ontológica em seu livro Après la finitude (Após a finitude), uma posição filosófica que não poderá deixar de ter ressonâncias com a própria crítica de Viveiros de Castro ao imperialismo epistemológico (de teor kantiano) na antropologia.

15 Claude Meillassoux foi um antropólogo africanista.
} 
estar esquecendo alguém) ${ }^{17}$. São três filósofos que dirigem essa coleção, cujo propósito é restabelecer os direitos da especulação metafísica em filosofia, um tema que está ressurgindo em vários lugares, na Inglaterra, nos Estados Unidos, por via, sobretudo, curiosamente, da blogosfera. A importância da blogosfera hoje na reflexão intelectual é imensa, e boa parte do que tenho acompanhado atualmente de discussão em filosofia está na blogosfera. Vim a conhecer uma revista de filosofia britânica na qual acabei indo publicar, ou melhor, eles me pediram para publicar um pedaço do Métaphysiques Cannibales nessa revista, chamada Collapse ${ }^{18}$. Uma revista de filósofos principalmente britânicos ou baseados no Reino Unido, mas voltada ao que eles chamam de filosofia continental, na verdade à filosofia pósestruturalista, principalmente. Essa filosofia ali se encontra com a science fiction, junta diversos projetos de exploração do pensamento que encontram pouco ou nenhum lugar na academia. Minha impressão é a de que os filósofos acadêmicos mal sabem da existência dela. Meu trabalho reflete um pouco essa minha exposição ao novo ambiente filosófico, que é um ambiente que mistura filosofia com antropologia, com ecologia, com science fiction, com teoria da literatura.

Falei hoje de manhã que o Métaphysiques não era um livro de filósofo; talvez nem precisasse dizer, era óbvio, mas como saiu numa coleção de filosofia talvez fosse preciso dizê-lo. Mas é um livro para filósofos sem dúvida; foi escrito para que os filósofos lessem. Um dos meus colegas franceses me disse "ah, esse seu livro não tem nada de novo... a parte antropológica é muito pouco original". Respondi: "é, mas não era para ter, não trago nenhuma verdade inaudita para os antropólogos, o livro não foi escrito para vocês, foi escrito para os filósofos lerem”. Nesse sentido é um livro de divulgação. Não é um livro de resultados originais de pesquisa. Ao mesmo tempo, o livro tem uma quantidade de parágrafos provocativos contra a antropologia francesa, escritos, na verdade, para os antropólogos lerem. Pois é claro que eles iriam ler. 0 livro é para filósofos, mas ele foi feito também para irritar

\footnotetext{
16 David Rabouin, pesquisador em filosofia no CNRS (no Recherches Epistémologiques et Historiques sur les Sciences Exactes et les Institutions Scientifiques - REHSEIS), com doutorado sobre Leibniz, é um dos organizadores da Coleção MetaphysiqueS.

${ }^{17}$ Além dos nomes citados por Viveiros de Castro, há aquele de Elie During, professor de filosofia na Université de Paris Ouest - Nanterre, que participa dessa coleção a que ele se refere.

180 endereço eletrônico da revista é: < $\underline{w w w}$.urbanomic.com/publications.php $>$.
} 
(no sentido puramente dermatológico do termo) certos antropólogos, ou certa antropologia local, que eu entendo que está muito atrasada (en retard sur, como se diz aqui). Que está fora de sincronia com essas coisas interessantes que estão acontecendo na blogosfera. Então o livro adota, às vezes, um tom um pouco insolente, ele foi escrito de propósito assim; aparentemente alcançou pelo menos esse resultado. Sei que ele irritou consideravelmente algumas porções da comunidade antropológica local. Sei também que o livro interessou a alguns setores da comunidade filosófica local, como dá testemunho a minha presença aqui, agora. Então, nesse sentido, o livro foi um sucesso. Apesar de eu não achar um livro especialmente bom, pois não traz nada de novo para mim, há nele algumas passagens que me esclareceram a mim mesmo. Nesse sentido, foi um livro útil; vai ajudar-me a produzir alguma coisa mais adiante; mas ele foi um livro escrito para trás e não para frente, no que me concerne. É um balanço. Mas fico muito feliz de ver filósofos como JeanChristophe Goddard ${ }^{19}$ e Pierre Montebello ${ }^{20}$ interessados no livro. Fiquei muito contente, dois anos atrás, por ter conseguido interessar Maniglier, que é um dos pensadores que considero mais estimulantes no momento. Ele disse algumas das coisas mais perceptivas e originais já ditas sobre o pensamento de Lévi-Strauss. Aprendi com ele imensamente. Ele diz que aprendeu alguma coisa comigo e tal. Na verdade, a gente se encontrou no meio do caminho, só que ele está começando e eu estou acabando, do ponto de vista da trajetória. Para mim foi uma agradabilíssima surpresa encontrar alguém com essa capacidade de pensar a antropologia de fora da antropologia, e para fora da antropologia. Maniglier, aliás, escreveu sobre Matrix ${ }^{21}$, escreveu sobre Rosemary's Baby22, está interessado em política sexual, em arte. Conecta direito indígena com luta ecológica e com luta pelo casamento gay. E pensa todas essas coisas em termos filosóficos também.

\footnotetext{
19 Jean-Christophe Goddard é filósofo, especialista em idealismo alemão e tradutor de Fichte na França, além de professor na Université de Toulouse 2 Le Mirail. Autor de estudos sobre Hegel, Fichte, Bergson, Deleuze e Derrida, ele dirige o programa de mestrado em filosofia Erasmus Mundus e foi um dos idealizadores do evento em torno do livro de Viveiros de Castro no FIPS 2011.

20 Pierre Montebello é professor de filosofia na Université de Toulouse 2 Le Mirail, com trabalhos sobre Bergson, Tarde, Ravaison e Deleuze.

${ }^{21}$ Referência ao filme de ficção científica dos anos de 1990, Matrix.

$22 \mathrm{O}$ bebê de Rosemary, filme dirigido por Roman Polanski.
} 
Esse tipo de criatividade e de ousadia, no meu entender, é absolutamente crucial, e não vejo isso acontecendo. Na academia é um desastre, acontece exatamente o contrário. [Há] um conservadorismo absurdo: é antropólogo dizendo que não pode haver casamento gay, porque isso vai contra o triângulo edipiano, a estrutura simbólica humana, essas besteiras; é antropólogo se declarando contra as cotas porque as cotas na universidade são a reafirmação do racismo. As cotas são fundamentais para expor o racismo, não para resolver o problema do racismo no Brasil.

Então, acho que, em suma, o Maniglier faz o que eu faço, nesse sentido, e muito melhor do que eu faço. É claro que ainda tenho um ou dois truques antropológicos para ensinar a ele. Para mim, esse foi um encontro muito importante. Maniglier é meu intercessor junto aos filósofos franceses, que começaram a me levar a sério (ou pelo menos assim parece!) graças principalmente a ele. Então, nesse sentido, está sendo uma grande experiência para mim, porque eu andava decepcionado, na verdade, com a França do pensamento; eu achava que ela estava indo ladeira abaixo. Continuo achando que a antropologia francesa está indo, em geral, por um caminho que não me interessa. Não vou dizer que é um caminho ruim, é apenas um caminho que não me interessa. E encontro na filosofia gente andando pelo caminho que me interessa, então acho ótimo que isso tenha acontecido. No que me concerne, se quiserem me considerar um filósofo aqui na França, c'est pas grave.

Primeiros Estudos: Ainda no contexto desse cruzamento do seu trabalho com a filosofia, poderíamos falar então em efeitos desse livro, Métaphysiques Cannibales, sobre o pensamento filosófico. Um desses efeitos talvez poderíamos chamar de geofilosófico - o senhor chega a falar disso no seu livro. Qual seria um efeito geofilosófico se compreendemos as metafísicas canibais como uma espécie de máquina de guerra contra uma certa metafísica ocidental, que o senhor bem caracteriza no seu livro como o fundamento de todos os colonialismos? Essa metafísica ocidental tem a ambição de determinar uma espécie de ponto de vista de Syrius, ou seja, aquele com base na qual todas as outras perspectivas de outras espécies e de outros povos são confundidas numa alteridade privativa comum. Qual o efeito geofilosófico do seu livro sobre esse tipo de metafísica? 
Eduardo Viveiros de CaStro: Geofilosofia é um conceito que eu gosto muito. Ele dá título a um capítulo do Qu'est-ce que la philosophie de Deleuze e Guattari (1991). Esse é um capítulo que define um programa ainda a ser cumprido. Os autores apenas erguem ali as balizas de um grande programa filosófico, a questão da geofilosofia. Por várias razões, não tiveram tempo de fazê-lo, ainda que se possa dizer - de fato, pode-se dizer com inteira tranquilidade - que o Milles Plateaux (1980) é o primeiro grande livro de geofilosofia do século XX. É um dos maiores livros de filosofia do século XX, aliás. Um livro centrado na ideia de que a filosofia tem que pensar a terra, a territorialização, a desterritorialização, e tem que pensar a não filosofia, o devir-povo da filosofia, o devir-mundo da filosofia. É o grande livro que lança isso. No Qu'est-ce que la philosophie? eles restabelecem e generalizam esse programa. Entendo o Métaphysiques Cannibales como uma espécie de nota de pé de página ou de caderno - como é que chama? De Primeiros Estudos, para citar uma revista célebre... - de primeiros estudos de geofilosofia, o equivalente aos primeiros estudos em antropologia na área da geofilosofia.

O que seria um esboço de geofilosofia tomando como referência o Brasil? Seria o quê? Seria essencialmente, primeiro de tudo, não se preocupar com a brasilidade do pensamento, esquecer essa questão. [Jorge Luis] Borges dizia: "eu não sou nacionalista, porque o nacionalismo é uma ideia europeia". Então, é a mesma coisa. Na geofilosofia, o que me interessa não passa pela brasilização, não brasilização, nacionalização, não nacionalização da filosofia ou do que quer que seja. Porque isso é patético, é uma coisa triste, e termina em uma camisa verde, um integralismo, uma teoria da mestiçagem, uma merda dessas qualquer. 0 que me interessa é pensar o que há, vamos chamar assim, de interessante, de novo, de possível no continente americano, nesse pedaço do planeta. E o que há de novo é o que há de antigo. 0 que há de novo tem 500 anos, são os índios. Quer dizer, tem 500 anos que nós "descobrimos", e 500 que nós ignoramos. É passando pelos índios - índios reais, índios imaginários, índios simbólicos, índios de carnaval, índios de Oswald de Andrade, índios da antropologia, índios de ficção, índios de novela, índios nus, índios vestidos, todos os índios -, é passando pelos índios, e pelos negros, pelos africanos, pelas minorias, que "nosso" pensamento vai se articular como "um" pensamento, vai poder ter, poder ganhar uma inflexão nova. 
Tentando corrigir - ou digamos, nuançar - esse meu suposto radicalismo, diria que há uma imensa tarefa a ser cumprida pela filosofia acadêmica, pela antropologia acadêmica no Brasil, e que tem que continuar a ser cumprida. Mas penso que, ao mesmo tempo, a universidade como um todo tem que começar a ficar antenada ao que está acontecendo no plano do pensamento, fora da universidade, às margens da universidade, por baixo, por cima, pelo lado. Fora do sistema de avaliação da Capes, do Qualis, dessas ferramentas "gerenciais" da produtividade, do rendimento. Partir para a internet, para a blogosfera, para o copy left, o open access, o informal, a periferia, o mangue, o baixio, o mato. Então não vai aí nenhuma crítica direta à reflexão filosófica tradicional nem ao trabalho antropológico padrão; acho que, ao contrário, eles têm que continuar existindo como o diapasão para a improvisação. Alguém tem que dar o tom e marcar o ritmo. Mas não confundamos o metrônomo com a música, nem o lá do diapasão com a harmonia.

Geofilosofia, como eu disse, é um conceito que me interessa. Mas me interessa também porque eu não fico inteiramente satisfeito - decerto por incapacidade minha de apreciar devidamente a complexidade do pensamento de Deleuze e Guattari - com a oposição que eles fazem, muito dramática, muito global, entre o que chamam de conceito e de figura no capítulo "Geofilosofia" de seu último livro. A noção de figura me parece ainda demasiado indeterminada. A de conceito é, ao contrário, perfeitamente determinada. O livro produz o conceito de conceito. Qu'est-ce que la philosophie? é um grande livro de filosofia precisamente porque ele nos dá o conceito de conceito; mas o conceito de figura, ao contrário, aparece apenas como conceito do não conceito, o conceito daquilo que não é conceito. É a China, é a Índia. Penso que é justamente aí que o antropólogo - que não é filósofo, e que trabalha nas sociedades da figura, no sentido em que Deleuze e Guattari dão ao termo, não no sentido que a palavra possa ter em outros idiomas filosóficos, em outras prosas teóricas - tem algo a fazer. Como determinar melhor o conceito de figura tal como ele aparece em Qu'est-ce que la philosophie?, isto é, como uma espécie de outro do conceito. Um outro que precede o conceito e ao mesmo tempo prepara o conceito. Os autores têm em mente, imagino, coisas como o I-Ching, como o yin/yang, como a filosofia hindu. Tudo isso seriam figuras da figura, imagens da figura, do "pré-conceito", ou do "ainda não conceito", ou de alguma coisa como uma 
alternativa ao conceito. Do conceito como "coisa" própria da filosofia, portanto, específico da Grécia, tendo, assim, uma contingência que lhe é própria. Nada contra isso, muito pelo contrário, acho que é isso mesmo, conceito é coisa de grego, quem o inventou foram os filósofos, não teria nenhuma razão para achar conceito entre os índios, mas é possível perfeitamente fazer conceito com os pensamentos indígenas. Não se trata de dizer "olha só, os índios também têm conceito". Isso seria ridículo, os índios não pediram para ter conceito, não pediram essa honra. Seria patético imaginar que a grande aspiração dos índios fosse virar filósofo; como se fosse a coisa mais importante do mundo, como se todo mundo quisesse ser filósofo quando crescer. Mas é perfeitamente possível pensar o pensamento indígena e tentar fazer conceitos com ele, com base nele, como se pode fazer conceito com base na arte, na literatura, na experiência de vida, em certas estéticas da existência. Então um programa que resta por cumprir é o programa de determinar, de uma maneira mais precisa e ao mesmo tempo mais variada, mais nuançada, o conceito de figura.

Enfim, isso é uma coisa que me interessa, não sei se eu terei condições de fazer nada parecido, mas é um pouco nessa direção que eu vou. Penso que autores como Oswald de Andrade ou Guimarães Rosa ou Clarice Lispector ou outros grandes pensadores brasileiros - coloco-os na categoria de pensadores brasileiros, como disse hoje de manhã - estão ocupados em desenvolver um pensamento não conceitual, mas que possui a potência de suscitar conceitos, de forçar a filosofia a produzir os conceitos adequados para essas, nesse caso literalmente, experiências de pensamento que são todos os escritos de Oswald, que são o Grande sertão [veredas], o Meu tio, o iarauetê, a Paixão segundo G. H., o Perto do coração selvagem... Momentos máximos do pensamento brasileiro do século XX. É interessante juntar essas coisas, enxergar essa linhagem que passa de Oswald de Andrade para Guimarães Rosa para Clarice Lispector e vice-versa. Pensamento antropofágico não é a mesma coisa que falar de índio comendo gente. É outra coisa e esses autores estão pensando isso.

Tome-se Meu tio, o iarauetê, por exemplo. Não é um texto sobre o deviranimal, é um texto sobre o devir-índio. Ele descreve como é que um mestiço revira índio, e como é que todo mestiço, quando vira índio - isto é, quando se desmestiça 
- o branco mata. Essa é que é a moral da história. Muito cuidado quando você inverter a marcha inexorável do progresso que vai do índio ao branco passando pelo mestiço. Quando você procura voltar de mestiço para índio como faz o onceiro do conto, você termina morto por uma bala disparada por um revólver de branco.

A paixão segundo $G$. $H$. é sobre o devir imperceptível e o devir-mulher de uma mulher, passando por um devir-barata que é meramente passagem. 0 interesse dela é atingir o neutro, o insípido e o amorfo, como ela chama: o pós-humano, o além-humano, a vida pura, a vida nua. 0 belíssimo texto derradeiro de Deleuze (2003), "Immanence, une vie..." ("A imanência: uma vida..."), parece-me prefigurado nesse texto fulminante de Clarice Lispector.

Juntar esses textos, juntá-los com questões indígenas, com as questões do pensamento indígena, com os devires-animais indígenas, com o devir-índio dos mestiços, com o devir-branco dos índios (o branco como minoria, última ironia indígena). Tudo isso me parece constituir um continente de pensamento que é preciso conhecer mais a fundo. Estamos aqui a anos-luz de distância dessas taxonomias, dessas explicações pseudo-neo-darwinistas, nas quais a antropologia hoje abunda, nas quais ela abunda hoje. [Estamos] no academicismo mais caretaço que se possa imaginar. Et j'en passe...

Primeiros Estudos: $O$ senhor falou em devir-índio do branco, toda essa experiência riquíssima também na literatura brasileira e também na música, experiência artística em geral, brasileira e cultural. O senhor acha possivel - e se sim, como - fazer uma leitura antropofágica, oswaldiana talvez, de Darcy Ribeiro, tirando toda aquela apropriação que foi feita dele justamente segundo a via de um nacionalismo, de uma brasilidade?

Eduardo Viveiros de Castro: Acho que sim. Uma das tarefas na minha agenda como é que chama aquela coisa, aqueles programinhas "to do" que tem sempre no computador? Coisas a fazer, to do... - é reler Darcy subtraindo do texto dele toda a prosódia ufanista nacionalista, a qual foi largamente imposta a ele por seu contexto histórico tão particular, e do qual ele não deixou de ser cúmplice, evidentemente. Mas o Darcy tem uma potência vital que extravasa de muito tudo isso, e que foi - 
tenho essa impressão - pego de mau jeito por seus admiradores. Darcy tinha o mesmo problema que vários outros pensadores - Deleuze é um caso, não que eles não tenham mais nada em comum, mas o problema comum é que raramente os admiradores fazem justiça ao admirado. É preciso saber ler o Darcy de um jeito um pouco a contrapelo. Vamos dizer assim: tirar todo o Mário de Andrade que insiste no Darcy e deixar só o Oswald de Andrade que existe nele. 0 aspecto antropofágico que o Darcy tem. O Darcy é algo a conquistar, a tarefa de reler o Darcy de um jeito interessante e inteligente. As leituras do Darcy são leituras repressivas, que usam o Darcy contra alguém, contra alguma coisa, para regular a atividade de pensamento alheia. "Ah, você não é nacionalista", "você não faz política o bastante," "você não é suficientemente brasileiro" - coisas desse quilate.

Primeiros Estudos: $O$ senhor falou da blogosfera e, por exemplo, publicou numa revista online, Cultura e Barbárie ${ }^{23}$, e agora tem também o twitter. E, por outro lado, há hoje estudantes indígenas fazendo mestrado em antropologia. É muito interessante ver que eles estão entrando justamente na academia, mas com a visão deles - há, por exemplo, antropólogos indígenas fazendo antropologia da ciência, lendo Stengers $^{24}$, Strathern 25, acho que lendo o senhor também, e o Latour etc. Então, por um lado os acadêmicos estão indo pra esses outros ambientes, digamos...

Eduardo Viveiros De CASTro: E os índios estão entrando na academia? Eu acho ótimo, acho que tem mais é que entrar mesmo. Acho sobretudo que tem que entrar desse jeito, tentando buscar objetos de estudo que não sejam eles próprios, porque a ideia de "ah, nós podemos fazer a nossa própria antropologia" sempre me pareceu... às vezes você ouve... "os índios não precisam mais de antropólogos porque eles agora estão em condições de fazer a sua própria antropologia"... me parece meio boba essa ideia, francamente. Não porque seja uma coisa que eles não possam fazer, mas porque, afinal de contas, o interessante da antropologia é você fazer antropologia dos outros, não a própria, acho eu. E quando você faz a própria você

\footnotetext{
23 Disponível em: <www.culturaebarbarie.org/sopro $>$.

24 Isabelle Stengers é uma filósofa contemporânea da ciência.

25 Marilyn Strathern é uma antropóloga britânica cujo trabalho de campo se concentrou na Melanésia e que exerce importante influência na antropologia simétrica e nos estudos de antropologia do gênero.
} 
faz para se alterar, não para se identificar. Então, acho ótimo que esteja começando a haver índios estudando os brancos ou outros índios. É muito interessante ver os Tukano indo estudar os Gê, os Gê indo parar na Guiana, ou um índio estudar a ciência feita em São Paulo.

Isso não é a mesma coisa do que a entrada dos movimentos indígenas na blogosfera, ok? 0 que também é uma conexão com o mundo do capitalismo tardio, mas ali tem de tudo. Tem desde blog de índios evangélicos fundamentalistas até um blog que eu vi há pouco tempo chamado "Nós somos patrimônio". Não sei se vocês já viram isso, não pude ainda estudá-lo direito, mas achei o nome sugestivo: “Nós somos patrimônio”. É sobre as culturas indígenas, escrito por eles. É uma coisa de um movimento indígena, não sei exatamente qual, porque não existe $o$ movimento indígena, mas movimentos indígenas em todas as direções.

Não sou das pessoas mais otimistas do mundo, devo dizer. Não penso que tudo isso vai ser para o melhor, que vai tudo terminar numa grande maravilha, uma grande união, fusão, sem nenhuma perda ou qualquer dano. Acho, ao contrário, que vai haver muita coisa ruim acontecendo, em termos de perda, de alienação, de equívoco, de essencialismo, de identificação, de culto da identidade. Marcio Goldman e eu demos um curso no Museu [Nacional] e uma entrevista para Cadernos de Campo falando desse curso (BARCElOs NeTo et al., 2007). Havia uma aula em nosso curso chamada "Identidade: isso pega?". Concluímos que pegava, que identidade era uma doença que pega mesmo, muito contagiosa. E acho que os índios, como pegaram gripe, sarampo, varíola, vão pegar identidade. Mas espero que eles desenvolvam imunidade, como desenvolveram e estão desenvolvendo, à gripe, ao sarampo e a outras doenças de branco. Que desenvolvam imunidade à identidade também, até porque eles não tinham isso antes de os brancos chegarem. É como a gripe, não tinham. Esse vírus foi introduzido, eles vão pegar, talvez produza estragos muito grandes, mas com o tempo, Deus ajudando, eles vão desenvolver resistência à identidade e quem sabe isso seja para o melhor, ainda que eu ache que o risco de haver um extermínio em massa, falando metaforicamente, de haver mortes em massa por intoxicação de identidade não é pequeno, mesmo porque o que o Estado mais quer é identidade. Não só ele distribui, atribui, gera e gere identidade, 
como ele precisa de identidade. Ele precisa que os índios se identifiquem como índios - ou não. Vamos ver como é que isso se resolve.

\section{Referências}

Agambem, G. (1993). A comunidade que vem. Trad. de António Guerreiro. Lisboa, Presença.

Barcelos Neto, A.; Ramos, D.; BÜHLER, M. S.; Sztutman, R.; Marras, S. (2007). "Abaeté, rede de antropologia simétrica: entrevista com Marcio Goldman e Eduardo Viveiros de Castro". Cadernos de Campo, vol. 14/15, p. 177-190.

Debord, G. (1997). A sociedade do espetáculo. Rio de Janeiro, Contraponto.

Deleuze, G. (2003). “Immanence, une vie...”. In: LAPoujADE, D. (org.).: Deux régimes de fous, Textes et Entretiens 1975-1995. Paris, Minuit.

Deleuze, G.; Guattari, F. (1980). Mille Plateaux. Paris, Minuit. . (1991). Qu'est-ce que la philosophie? Paris, Minuit.

LÉVI-STRAuSS, C. (1952). Race et Histoire. Paris, UnEsCo.

Viveiros DE CASTRo, E. (2002). “O nativo relativo”. Mana [online], vol. 8, n.1, p. 113148. Disponível em: <http://dx.doi.org/10.1590/S0104-93132002000100005>. . (2007). "Filiação intensiva e aliança demoníaca". Novos Estudos CEBRAP, vol. 77, p. 91-126.

(2009). Métaphysiques Cannibales. Paris, PUF. 